\title{
9. Naming the scale of nature
}

\author{
Juliet Clutton-Brock
}

\section{Introduction}

As an archaeozoologist and mammalogist, I spent 30 years in the Osteology Room of the British Museum (Natural History), later named the Natural History Museum, and for a number of those years the visits of Colin and Phyll Groves enlivened the Mammal Section, not only with taxonomic discussions but also with memorable lunches in the nearby Bute Street cafés. It was the period during which the analysis of animal remains from archaeological sites was developing into a multidisciplinary science, and arguments and discussions on nomenclature prevailed in many international conferences. At the seminal conference on 'Equids in the Ancient World' held in Tübingen University in 1984 Colin's knowledge of equid taxonomy led the discussions (Groves, 1986).

In the context of archaeozoology and proposals for standardising the nomenclature of domestic animals that I have participated in with Colin, I give below a summary of the ways in which organisms in the animal kingdom have been named. This begins with the first written records in the prehistoric period, and progresses through the methods of Aristotle to the naturalists of the eighteenth century, Linnaeus, and modern taxonomy. The summary is followed with an outline of the suggestions and arguments for and against the formal naming of domestic animals that surrounded the development of archaeozoology in the twentieth century.

\section{The beginnings}

Since early hominins first began to use words to describe their surroundings they must have had names for the plants and animals around them, and these names would have been distinctive in the myriad languages that evolved around the world. However, it is only since the invention of written records that names could live on and be transcribed from ancient languages that have become extinct.

It is in the third millennium BC that the first written records of animal names begin to appear, and it is evident that elaborate systems of nomenclature already existed. To take an example from the 1984 Tübingen conference, the 
names for the different species and hybrids of equids, which were known to the Sumerians and Akkadians in ancient Mesopotamia, were decoded, as follows, from cuneiform texts by Nicholas Postgate (1986):

$$
\begin{array}{ll}
\text { anse } & =\text { generic term for equid, or E. asinus } \\
\text { anse-DUN.GI or anse-LIBIR } & =E \text {. asinus } \\
\text { anse-eden-na } & =E \text {. hemionus } \\
\text { anse-BARxAN } & =E \text {. asinus } x \text { E. hemionus } \\
\text { anse-zi-zi or anse-kur-ra } & =E \text {. caballus }
\end{array}
$$

By the time that Genesis is believed to have been first recorded in writing, probably during the first millennium BC there must have been fully developed nomenclatures for every living and non-living thing in a people's environment. So it is not surprising that the Hebrew legend of creation included an explanation for the origin of animal names: 'and out of the ground the Lord God formed every beast of the field, and every fowl of the air; and brought them unto Adam to see what he would call them: and whatsoever Adam called every living creature, that was the name thereof' (Genesis 2, 19).

Furthermore, after the Flood had retreated, the Hebrew God

[B]lessed Noah and his sons and said unto them, Be fruitful and multiply, and replenish the earth.

And the fear of you and the dread of you shall be upon every beast of the earth, and upon every fowl of the air, upon all that moveth upon the earth, and upon all the fishes of the sea, into your hand are they delivered.

Every moving thing that liveth shall be meat for you; even as the green herb have I given you all things (Genesis 9, 1-3).

This belief that everything in the world had been created by God for the benefit of humans seems not to have been inherited so rigidly by the ancient Egyptians but it certainly was by the ancient Greeks and its spread to Christianity was due in great part to the enormous influence of Aristotle's great works. This lasted in Western Europe until the time of Darwin, although doubts set in after the spread of new animals and plants (unknown to the classical world) from the Americas in the sixteenth century.

Aristotle was born in $384 \mathrm{BC}$ and he died, aged 63 in $322 \mathrm{BC} .{ }^{1}$ His approach to the natural world was teleological, that is, he believed that everything in Nature

\footnotetext{
1 The sections on Aristotle and Linnaeus, in this chapter, were previously given as part of a paper presented to a conference, In the Company of Animals, held at the New School for Social Research, New York, in April
} 
had a purpose, and this purpose was for the benefit of mankind (Clutton-Brock, 1999a). He wrote, 'plants are evidently for the sake of animals, and animals for the sake of Man; thus Nature, which does nothing in vain, has made all things for the sake of Man' (Peck, 1970: xli).

Aristotle's investigations into zoology are compiled into a series of books (authoritatively translated in the Loeb Library), known as the History of Animals (Peck, 1965, 1970; Balme, 1991) the Generation of Animals (Peck, 1990), and the Parts of Animals, the Movement of Animals, and the Progression of Animals (Peck and Forster, 1983). He wrote about more than 500 species including shellfish, insects, birds, reptiles, and quadrupeds, with humans being treated in the same way as all other animals. Aristotle's descriptions of animals were much quoted in the later classics, such as Pliny's Natural History (c. AD 77-79) and Aelian's (AD 175-235) On Animals, and it is from the classical writers on natural history that the long tradition of naming animals and plants in Latin was inherited.

Division of the animal kingdom is older than Aristotle; in Plato's philosophy the highest genus was divided by means of differentiae into subsidiary genera and each of these was then divided and subdivided by dichotomy, until the ultimate species was reached. At the upper end of Aristotle's scale he had main groups such as birds and fish, which were his genera, and at the lower end the commonly named animals such as dog, cat, eagle, etc., which were his species, but normally the intermediate stages are missing.

Aristotle did recognise a Scale of Nature but the rungs of his ladder were not the stages of a taxonomic scheme, and there is no evidence that he felt they should be. His purpose was not to construct a taxonomic system, but to collect data for ascertaining the Causes of observed phenomena; and this was to be done by looking to see whether certain characteristics were regularly found in combination: this was how the clues to the Causes would be brought to light. Aristotle believed that human beings were animals but at the same time he was certain that all other animals existed for the sake of Man. He asserted that it was impossible to produce a neat hierarchical order on the basis of obvious physical differences because these cut across each other.

Like the ancient civilisations of Mesopotamia and Egypt, that of classical Greece was a stratified society ruled by powerful hierarchies and in which all manual work was carried out by slaves. It is therefore only to be expected that the Greek philosophers would view the natural world as a gradation from the lowest to the highest, or as a scale of perfection, which was to become known as the Scale of Nature or the Great Chain of Being (Lovejoy, 1936).

1995. The proceedings were published in Clutton-Brock (1999a). 
Taxonomic Tapestries

\section{The Five Predicables}

In the European-speaking world, until well into the eighteenth century, the method of classification of all organisms was based on the Five Predicables. This was a hierarchical system that had been adapted from Aristotle's classification of logic, as written in his work known as the Topics. The Five Predicables were genus, species, differentia, property, and accident. They were clearly defined by Simpson (1961: 24).

\section{Linnaeus and binomial classification}

Carl Linnaeus (1707-1778) was clearly an obsessional organiser who classified not only the plant and animal kingdoms but also the minerals and the kinds of diseases known in his day. Since the time of Aristotle, animals and plants had been named in Latin by using the genus and the differentia from the Five Predicables of classification. The two together made up the definition, which could be used as the name. However, with the classification and naming of more and more species over time, the differentia often became very long. The great innovation of Linnaeus was in creating the binomial or binary system by taking the old name for the genus and adding a single name from the many that had been used in the differentia, as the species.

Linnaeus's definitive tenth edition of his Systema Naturae (1758) was written in Latin and the long introduction has been seldom translated, although it is full of fascinating comments on eighteenth century attitudes to animals, as well as the first use of the term Mammalia. The translation of Robert Kerr (1792) has the title The Animal Kingdom or Zoological System of the Celebrated Sir Charles Linnaeus. After the short introduction there is a chapter translated as, 'The Empire of Nature', which begins with quotations from Aristotle on the Causes, and from the Roman writers Seneca (4 BC-AD 65) and Pliny the Elder (AD 2379). Linnaeus followed Aristotle in believing that the three kingdoms of nature: minerals, vegetables, and animals met together in the Order of Zoophytes, and also in the belief from Genesis that everything in the world was created for Man, for he wrote: 'Hence one great employment of man, at the beginning of the world, must have been to examine created objects, and to impose on all the species names according to their kinds'.

Unlike his predecessors, Linnaeus saw that the unit of classification had to be the species, and he produced a strict hierarchical classification that ended at its summit with the Kingdom. Linnaeus summarised his ideas as follows (Kerr, 1792: 22-23): 
Classes and Orders are the creatures of human invention, while the division of these into Genera and Species is the work of Nature. All true knowledge refers finally to the species of things, while at the same time, what regards the generic divisions is substantial in its Nature.

... God, beginning from the most simple terrestrial elements, advances through Minerals, Vegetables, and Animals, and finishes with Man. Man on the contrary, reversing this order, begins with himself, and proceeds downwards to the materials of the earth. The framer of a systematic arrangement begins his study by the investigation of particulars, from which he ascends to more universal proportions; while the teacher of this method, taking a contrary course, first explains the general propositions, and then gradually descends to particulars.

\section{Vernacular names and early modern classifications}

While the naturalists wrestled with trying to produce meaningful classifications of the natural world, the general population of each country of course had their own vernacular names for every living thing, and these names could be enormously complicated. This was especially so when the animal was part of a ritual such as the royal hunts of Medieval Europe. In modern English a male red deer is a stag, but in the Laws of Venery the red deer was a beast of the chase and the stag had many names, depending on its age. In its first year it was a calf, in its second, a brocket, in its third a spayard, in its fourth a staggard, in its fifth a hart of ten, and in its sixth a hart (Clutton-Brock, 1984). When the meat of an animal was to be eaten it also had a separate name and it was from the Normans that the English names, venison, beef, and pork were adopted.

Throughout the Medieval and early modern periods animals and plants were named according to their uses to humans and this applied to domestic animals as much as to wild ones. Thomas (1983: 55) quotes the sixteenth century book Of English Dogges, by Dr John Caius in which there were three categories of dogs: a 'generous' kind, used in hunting or by fine ladies; a 'rustic' kind used for necessary tasks, and a 'degenerate', currish kind, used as turnspits and for other menial purposes. This way of classifying dogs by their uses to humans was echoed by Linnaeus who 200 years later divided the dog (Canis familiaris) into 11 separate species, which included the sheep dog (Canis domesticus) and the turnspit (Canis vertagus). 
Taxonomic Tapestries

\section{After Linnaeus: Modern taxonomy and nomenclature}

The fundamental unit of all classifications, including those of Aristotle and Linnaeus, is the species, which is composed of a population of interbreeding organisms. To Linnaeus, and to most biologists until the second half of the twentieth century, a species was considered to be a group of animals all of which were supposed to be identical with a type, officially recognised as such and preserved in a public institution. Following the growth of modern taxonomy, however, it was soon realised that a species comprises a population that is inherently variable in morphology and therefore the type specimen can have no special role in identifying other specimens. As explained in Simpson (1961: 31), 'A nomenclatural type is simply something to which a name is attached by purely legalistic convention'.

There is a commonly held view that the separation of two species can be determined by whether or not they will produce fertile offspring when interbred. However, on its own, the state of fertility of hybrid offspring is an inadequate means of defining a species. Many mammals that are normally considered to be good species will interbreed, although, because of a behavioural barrier, they may not usually do so in the wild, and their offspring will be fertile, for example the dog, wolf, jackal, coyote, and dingo will all interbreed and produce fertile offspring (Gray, 1972).

How then is the species to be defined? Since first proposed by Mayr (1940) an often-used definition has been the 'biological species concept'. This has gone through several revisions and expansions in the last 60 years, not least by Mayr himself, but remains essentially the same and is: a species is a group of interbreeding natural populations that is genetically isolated from other such groups as a result of physiological or behavioural barriers. However, Colin Groves argues (pers. comm., 27 July 2012) that:

The Biological Species Concept gives no guidance in the case of allopatric forms; it does not satisfactorily cover cases where two parapatric taxa, which are homogeneous within their ranges, nonetheless interbreed where their ranges meet; and DNA studies show that there has been far, far more interbreeding between perfectly 'good' species, even sympatric ones, than we would have guessed.

Groves prefers the Phylogenetic Species Concept of Cracraft (1983) who described his views thus:

As the 'biological species concept' really doesn't work, let us define species as being populations which are 'diagnosable', meaning that they 
differ $100 \%$ from each other; you can always recognise individuals as belonging to a particular species (except in the case of demonstrable hybrids); they have fixed heritable differences between them; they are (in cladistic terms) the terminals on a cladogram - however one wishes to put it. ${ }^{2}$

Until well into the twentieth century there were no fixed concepts of what constituted or distinguished species, subspecies, or breeds. Linnaeus believed there were several species of domestic dogs and even Darwin was not sure of the distinctions. The subspecies is the lowest unit that may be included in zoological taxonomy and subspecies are designated with a trinomial, e.g. Canis lupus arabs (in botany, variations can also be given a Latin name). The status of the subspecies has been discussed at length by Simpson (1945: 16; 1961: 171). The modern definition that I consider most useful states: a subspecies is a distinctive, geographical segment of a species, that is it comprises a group of wild animals that is geographically and morphologically separate from other such groups within a single species.

Today, it is generally agreed that the end product of animal domestication is the breed and not the species or subspecies, and breeds are not given Latin names. My definition of a breed is: a group of animals that has been bred by humans to possess uniform characters that are heritable and distinguish the group from other animals within the same species. A breed parallels a subspecies, except that, whereas a subspecies is restricted to a geographical region a breed is not (Clutton-Brock, 1999b: 40).

But how should domestic forms be named? Up to the time of Linnaeus and beyond, there were no problems - domestic breeds were seen as species or subspecies in their own right, and the nineteenth and early twentieth century archaeozoologists were happy to allocate the bones they found associated with human settlements to taxa with Linnaean binomials and trinomials. Sheep remains were called Ovis aries studeri or Ovis longipes egyptius, while dog remains were Canis poutiatini or Canis familiaris matris-optimae.

The central difficulty for the naming of domestic species hangs on whether or not they should be considered as conspecific with their wild progenitors. To Linnaeus it was obvious that the dog was a separate species from the wolf, but to archaeozoologists who work on the identification of sub-fossil animal remains at the interface between the wild species and their earliest domesticated descendents there may be little or no evidence of an osteological and therefore a taxonomic distinction. In order to try to overcome this problem and with a widespread view that domesticates should be treated as conspecific with their

2 Their position as terminals on a cladogram is the origin of the 'phylogenetic' part of the name (Groves, pers. comm., 4 March 2013). 
assumed progenitors, several different systems of nomenclature have been devised for domestic mammals, as reviewed by Gautier (1993). Although none has received international recognition, the most widely accepted system was that proposed by Bohlken (1961). Bohlken's solution was to call the domestic form by the first available name for the wild species, followed by the linking word 'forma' (f.) and then by the earliest name, according to the rule of priority, for the domestic animal. In this way we would have Canis lupus $\mathrm{f}$. familiaris $\mathrm{L}$. for the dog and Capra aegagrus f. hircus L. for the domestic goat. This arrangement is, however, clumsy and it has the disadvantage that it assumes certain identification of the wild progenitor, which for some domestic animals, for example the ferret, may never be established.

At one time, I also proposed that domestic species should be excluded from formal nomenclature but I have come to believe that domestication is an evolutionary process and if the domestic form of an animal is for all intents and purposes separated reproductively from the wild form then it should be classified as a separate species. It is then valid to use the Linnaean names, which have the great benefit of being widely known and in general usage.

If the Linnaean names are used for domestic mammals there has been a problem with certain wild species that were given the same names as the domestic by Linnaeus. When he was familiar with both the wild and the domestic form of a species and they looked alike, as with his native reindeer, Linnaeus gave them the same name, Cervus tarandus, now called Rangifer tarandus. On the other hand because he failed to see the relationship between the wolf and the dog he gave them the separate species names, Canis lupus and Canis familiaris. With yet others, for example the goats and sheep, he had no knowledge of the wild ancestor and so he named only the domestic form (see Clutton-Brock, 2012, Appendix, for the list of relevant species). In order to get over the difficulty of using say the Linnaean name Equus asinus for the African wild ass as well as for the donkey it has become usual to use the next available name according to the International Code of Zoological Nomenclature (ICZN) for the wild species, which is Equus africanus.

As a convention among zoologists and archaeozoologists this system of nomenclature worked well but it was not in accord with the rules of the ICZN and in the chapters on the Perissodactyla and Artiodactyla in the 1993 edition of the influential Mammal Species of the World edited by Wilson and Reeder, names were used for wild species irrespective of whether they were first described on a wild or a domestic form. Thus the Linnaean names Equus asinus and Equus caballus were used for both the wild and domestic forms of ass and horse respectively. It was clearly time to stabilise the nomenclature of the 15 wild species that Linnaeus had named on domestic forms. Accordingly, Anthea Gentry, Colin and I put a Case to the ICZN to conserve the usage of specific 
names for wild animals that are antedated by or are contemporary with names based on domestic animals (Gentry et al., 1996). Case 3010 was presented and for six years Comments for and against the Proposal went to the ICZN. Finally, the Commission voted on the Case - the names were to be conserved and the ruling was published (ICZN, 2003).

The controversy surrounding the ruling on these names may seem arcane to non-taxonomists, but in fact it is of considerable importance. For example the extinct aurochs would, strictly, have to be named Bos taurus primigenius, as indeed it still is in the latest edition of Wilson and Reeder (2005: 692-693), thus making it a subspecies of the domestic ox. It must be emphasised, however, that this ruling on the conservation of these names is for wild species and it does not affect the taxonomic status and nomenclature of domestic forms.

So what should be done to settle the continuing discussion about naming the domestic forms? After 40 years of consideration and several changes of view I now believe that if the domestic form of an animal is for all intents and purposes separated reproductively from the wild form then it should be classified as a separate species. It is for this reason that I, together with other mammalogists, including Colin, have argued that domestic animals should not be excluded from formal zoological nomenclature and that the traditional Latin binomial names such as Capra hircus and Ovis aries should hold (Clutton-Brock, 1999b, 2012; Gentry et al., 2004).

Nomenclature is the backbone of taxonomy, but I think it is important to remember its subjective element, and to support my view on this I will discuss the different formal names that have been given to the dingo over the past 50 years. Until the 1970s the dingo was generally known as the wild dog of Australia and it was not paid taxonomic attention, but then its depredations on livestock turned the sheep farmers against it and biologists and pest controllers were called in to study its behaviour. In 1973 Alan Newsome and colleagues published an account of the dingo in the Australian Meat Research Committee Review in which they named it Canis familiaris dingo. The aim of the work was, 'to provide the basic biological data to devise rational and effective control programs'. And by naming the dingo as a subspecies of domestic dog (C. familiaris) the biologists were justifying its control.

This justification was increased by the work of Laurie Corbett who with his morphological study of dingoes and Thai dogs claimed that 'dingo-like canids' were widespread throughout Southeast Asia (Corbett, 1985). The dingoes of Australia thereby lost their unique status and they could be classified as pests. Then in the 1990s, and after the notoriety of the Azaria Chamberlain Case (1980), the dingo began to be named Canis lupus dingo, and this trinomial remains today in numerous online publications and on the latest IUCN Red List of Vulnerable 
Species. As a subspecies of wolf and a wild carnivore, it may be controlled when considered necessary but also conserved. However, genetic studies have now shown that the dingo was introduced to Australia possibly from South China and possibly at a single occasion, before the Neolithic expansion from Taiwan (Savolainen et al., 2004; Oskarsson et al., 2012). Since humans brought these first dogs to Australia, they have lived, bred and undergone natural selection in the wild, isolated from other canids until the arrival of Europeans. The case is clear to me that this unique dog should be recognised as part of the living heritage of Australia and it should revert to its first Latin name of Canis dingo Meyer, 1793, as argued by Crowther and others (2014). And finally I am pleased to learn online that the Merigal Dingo Sanctuary in Bargo (New South Wales), which I visited with Colin in 1987, is still active and promoting the conservation of dingoes.

\section{References}

Balme DM. [Transl.] 1991. Aristotle Historia Animalium. Books VII-X. Loeb Classical Library. Cambridge, MA and London: Harvard University Press.

Bohlken H. 1961. Haustiere und zoologische Systematik. Zeitschrift für Tierzüchtung und Züchtungsbiologie 76:107-113.

Clutton-Brock J. 1984. The master of game: The animals and rituals of Medieval venery. Biologist 31(3):167-171.

Clutton-Brock J. 1999a. Aristotle, the scale of nature, and modern attitudes to animals. In: Mack A, editor. Humans and other animals. Columbus: Ohio State University Press. pp. 5-24.

Clutton-Brock J. 1999b. A natural history of domesticated mammals. 2nd edition. Cambridge: Cambridge University Press \& The Natural History Museum.

Clutton-Brock J. 2012. Animals as domesticates a world view through history. Michigan: Michigan State University Press.

Corbett LK. 1985. Morphological comparisons of Australian and Thai dingoes: A reappraisal of dingo status, distribution and ancestry. Proc Ecol Soc Australia 13:277-291.

Cracraft J. 1983. Species concepts and speciation analysis. Current Ornithology $1: 159-187$.

Crowther MS, Fillios M, Colman N, Letnic M. 2014. An updated description of the Australian dingo (Canis dingo Meyer, 1793). J Zool 293(3):192-203. 
Gautier A. 1993. 'What's in a name?' A short history of the Latin and other labels proposed for domestic animals. In: Clason A, Payne S, Uerpmann H-P, editors. Skeletons in her cupboard Festschrift for Juliet Clutton-Brock. Oxbow Monograph 34, Oxford: Oxbow Books.

Gentry A, Clutton-Brock J, Groves CP. 1996. Case 3010. Proposed conservation of usage of 15 mammal specific names based on wild species which are antedated by or contemporary with those based on domestic animals. Bull Zool Nomencl 53(1):28-37.

Gentry A, Clutton-Brock J, Groves CP. 2004. The naming of wild animal species and their domestic derivatives. J Archaeol Sci 31:645-651.

Gray AP. 1972. Mammalian hybrids. Commonwealth Agricultural Bureau.

Groves CP. 1986. The taxonomy, distribution, and adaptations of Recent equids. In: Meadow RH, Uerpmann H-P, editors. Equids in the Ancient World I. Wiesbaden: Beihefte zum Tübinger Atlas des Vorderen Orients. pp. 11-65.

International Commission on Zoological Nomenclature (ICZN). 2003. Opinion 2027 (Case 3010). Usage of 17 specific names based on wild species which are predated by or contemporary with those based on domestic animals: conserved. Bull Zool Nomencl 60(1):81-84.

Kerr R. 1792. The animal kingdom or zoological system of the celebrated Sir Charles Linnaeus; Class I Mammalia. London: J. Murray.

Linnaei C. 1758 [1956]. Systema Naturae. A photographic facsimile of the first volume of the tenth edition (1758) Regnum Animale. London: British Museum (Natural History).

Lovejoy AO. 1936. The great chain of being. Cambridge, MA: Harvard University Press.

Mack A, editor. 1999. Humans and other animals. Columbus: Ohio State University Press.

Mayr E. 1940. Speciation Phenomena in Birds. The American Naturalist 74:249278.

Newsome AE, Corbett LK, Best LW, Green B. 1973. Australian Meat Research Committee Review, No. 14.

Oskarsson MCR, Klütsch CFC, Boonyaprakob U, Wilton A, Tanabe Y, Savolainen P. 2012. Mitochondrial DNA data indicate an introduction through mainland Southeast Asia for Australian dingoes and Polynesian domestic dogs. Proc Royal Soc Lond B 279(1730): 967-974. 
Peck AL. [Transl.] 1965. Aristotle Historia Animalium. Books I-III. Loeb Classical Library. Cambridge, Mass.: Harvard University Press \& London: Heinemann.

Peck AL. [Transl.] 1970. Aristotle Historia Animalium. Books IV-VI. Loeb Classical Library. Cambridge, MA and London: Harvard University Press.

Peck AL. [Transl.] 1990. Aristotle Generation of animals. Loeb Classical Library. Cambridge, MA and London: Harvard University Press.

Peck AL, Forster ES. [Transl.] 1983. Aristotle Parts of animals, movement of animals, progression of animals. Loeb Classical Library. Cambridge, MA: Harvard University Press \& London: Heinemann.

Postgate, JN. 1986. The equids of Sumer, again. In: Meadow RH, Uerpmann H-P, editors. Equids in the Ancient World I. Wiesbaden: Beihefte zum Tübinger Atlas des Vorderen Orients. pp. 194-206.

Savolainen P, Leitner T, Wilton AN, Matisoo-Smith E, Lundeberg J. 2004. A detailed picture of the origin of the Australian dingo, obtained from the study of mitochondrial DNA. Nat Proc Acad Sci 101:12837-12890.

Simpson GG. 1945. The principles of classification and a classification of mammals. Bull Am Mus Nat Hist 85: vii-xvi, 1-350.

Simpson GG. 1961. Principles of animal taxonomy. New York and London: Columbia University Press.

Thomas K. 1983. Man and the natural world: Changing attitudes in England 1500-1800. London: Allen Lane.

Wilson DE, Reeder DAM, editors. 2005. Mammal species of the world: A taxonomic and geographic reference. 2 vols. 3rd edition. Baltimore. 
This text is taken from Taxonomic Tapestries: The Threads of Evolutionary, Behavioural and Conservation Research, edited by Alison M Behie and Marc F Oxenham, published 2015 by ANU Press, The Australian National University, Canberra, Australia. 